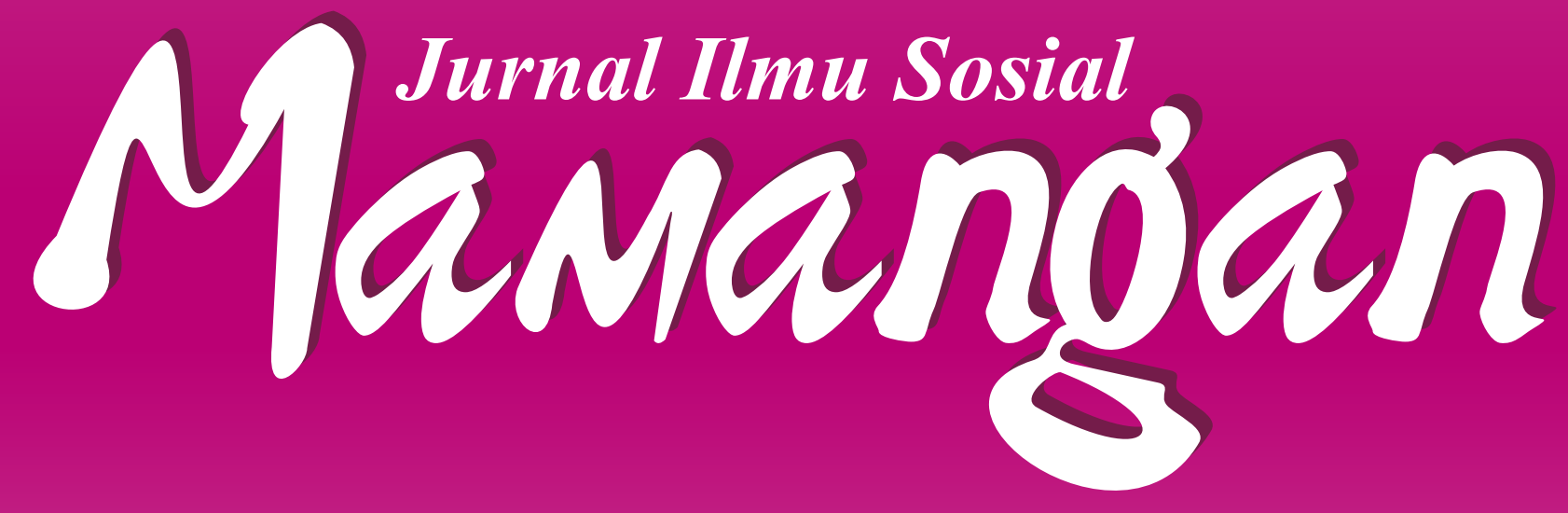

Seni Tradisi, Jatidiri dan Strategi Kebudayaan

Heddy Shri Ahimsa-Putra

Sejarah dan Nilai Songket Pandai Sikek

Silvia Devi

Budaya dalam Lintasan Sejarah: Booming Nonton Bioskop di Padang Tempo Dulu

Meri Erawati

Paradoksal Gaya Sosial Global; Kajian Budaya dalam Memahami Kesadaran Kolektif di Tengah Booming Batu Akik

Silfia Hanani

Gaya Kehidupan Malam Remaja di Kota Padang; Suatu Kajian Subkultur di Tempat Hiburan Malam Kota Padang

Faishal Yasin

Perlawanan Kaum Muda terhadap Hegemoni Radikalisme Agama dalam Bentuk-Bentuk Budaya Populer

Yusar

Gaya Interaksi \& Integrasi Sosial Anak Muda Rantau: Kasus Mahasiswa Kost di Air Tawar Barat, Kota Padang Darmairal Rahmad 


\section{PROGRAM STUDI PENDIDIKAN SOSIOLOGI STIIIP PGRI SUMATEPA BARAT}

\section{Visi}

"Menjadi Program Studi yang terkemuka di bidang pendidikan keguruan sosiologi dan kompetitif secara nasional di tahun 2026"

\section{Misi}

$>$ Melaksanakan dan mengembangkan pendidikan dan pengajaran yang berbasis kepada pengembangan kecerdasan intelektual (hard skill) dan kecerdasan emosional (soft skill) untuk memperoleh kecakapan hidup (life skill),

> Melaksanakan dan mengembangkan penelitian dan pengabdian di bidang pendidikan dan pengajaran serta bidang lain sesuai dengan keilmuan fakultas dan program studi,

$>$ Mengembangkan Ilmu Pengetahuan, Teknologi, dan Seni (IPTEKS) yang dilandasi profesionalisme,

$>$ Menyelenggarakan perguruan tinggi yang akuntabel, efisien, efektif, transparan, relevan dan mandiri,

$>$ Mengembangkan kerjasama dengan berbagai lembaga/instansi terkait dan stakeholders untuk keberlanjutan pelaksanaan program dan/atau pembukaan program studi baru. 


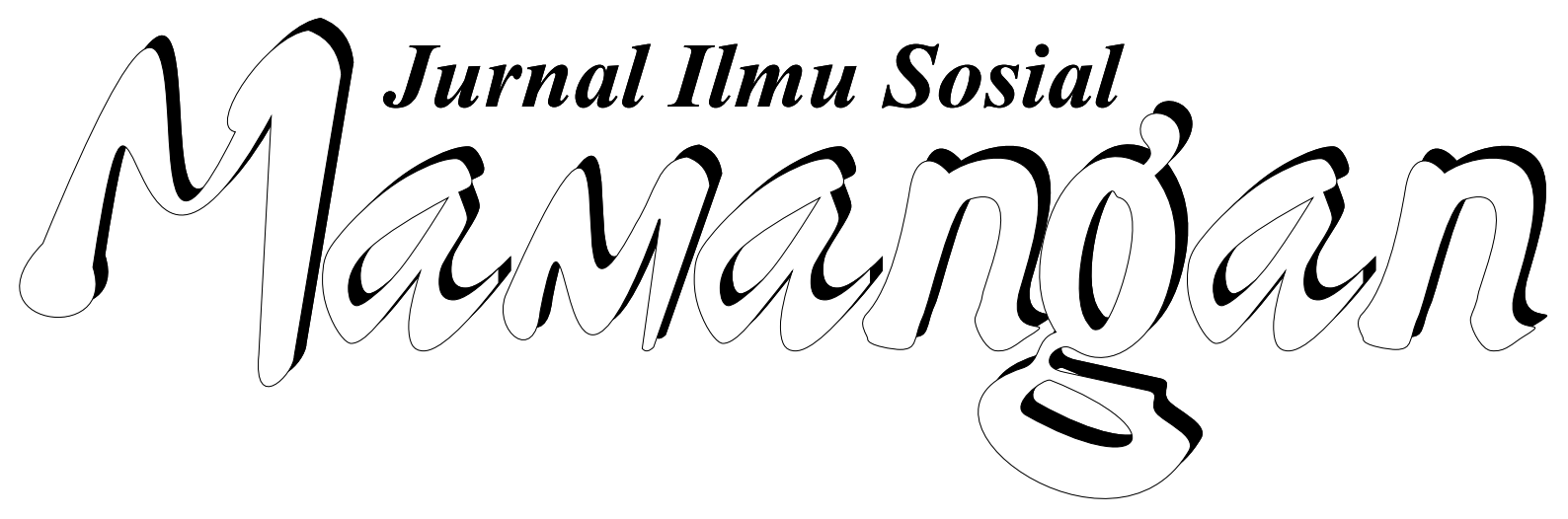




\section{一挑一 \\ Jurnal Ilmu Sosial Mamangan}

Volume 2, Nomor 1, Januari-Juni 2015

\section{Mitra Bestari}

Prof. Dr. Afrizal, MA. (FISIP, Unand Padang)

Prof. Dr. Badaruddin, M. Si. (FISIP, USU Medan)

Dr. A. Latief Wiyata, M. Si. (Universitas Jember, Jember)

Dr. Fikarwin Zuska, M. Si. (FISIP, USU Medan)

Nurus Shalihin, M. Si., Ph.D. (Fak. Ushuluddin IAIN Imam Bonjol Padang)

Dr. Semiarto A. Purwanto, M. Si. (FISIP, UI Jakarta)

Dr. Wahyu Wibowo, M. Si. (Universitas Nasional, Jakarta)

\section{Dewan Redaksi}

Dr. Zusmelia, M. Si.

Dr. Maihasni, M. Si.

Firdaus, S. Sos., M. Si.

\section{Pemimpin Redaksi/Editor}

Firdaus, S. Sos., M. Si.

\section{Anggota Redaksi}

Ariesta, M. Si.

Dian Kurnia Anggreta, S. Sos., M. Si.

Faishal Yasin, S. Sos., M. Pd.

Ikhsan Muharma Putra, M. Si.

Rio Tutri, M. Si.

Sri Rahayu, M. Pd.

Yuhelna, MA.

ISSN: 2301-8496

viii +109 halaman, $21 \times 29 \mathrm{~cm}$

\section{Alamat Redaksi:}

Laboratorium Program Studi Pendidikan Sosiologi, STKIP PGRI Sumbar Kampus STKIP PGRI, Jl. Gunung Pangilun, Padang, Sumatera Barat

Email: redaksimamangan@gmail.com \& daus_gila@yahoo.com

\section{Penerbit:}

Laboratorium Program Studi Pendidikan Sosiologi, STKIP PGRI Sumbar 


\section{PENGANTAR REDAKSI}

$\mathrm{K}$

ebudayaan merupakan produk yang dihasilkan oleh manusia, baik dalam bentuk ide, tindakan maupun karya. Yang terakhir disebut merupakan produk kebudayaan yang paling kongkrit dan termati dalam masyarakat. Kebudayaan terus diproduksi oleh manusia sesuai dengan zaman dan tantangannya untuk memenhi kebutuhan hidup mereka saat itu. Oleh karena kebudayaan terus diprosukdi oleh manusia, maka kebudyaan terus berdinamika sesuai dengan ruang dan waktu. Proses dinamika tersebut kadang berjalan dengan lambat dan kadang berjalan dengan cepat.

Respon terhadap dinamika kebudayaan juga berbeda berdasarkan kelompok. Paling tidak terdapat tiga kelompok berbeda menurut redaksi dalam menanggapi dinamika kebudayaan. Kelompok pertama adalah kelompok yang resah dengan dinamika kebudayaan, kedua kelompok yang senang dengan dinamika dan ketiga kelompok yang berada pada titik keseimbangan dalam melihat dinamika kebudayaan. Terlepas dari tiga kelompok yang ada, redaksi menyadari bahwa dinamika kebudayaan pasti akan berlangsung kapan saja dan dimana saja. Oleh karenanya, banyak bentuk kebudayaan baru yang dihasilkan dan banyak kebudayaan lama ditinggalkan.

Menyadari bahwa proses dinamika kebudayaan akan menghasilkan bentuk kebudayaan yang baru dan kebudayaan lama ditinggalkan, pada edisi ini redaksi mengambil tema-tema tulisan menyangkut kebudayaan. Tulisan-tulisan yang ada bicara dalam tema kebudayaan dengan berbagai perspektif dan pendekatan. Pendekatan itu mulai dari sejarah, hingga perlawanan, sehingga tulisan-tulisan dalam edisi ini disumbangkan oleh mereka dengan latar belakang yang berbeda.

Tulisan pertama disumbangkan oleh Prof. Heddy Shri Ahimsa-Putra, Guru Besar UGM. Dalam tulisannya Ahimsa-Putra menguraikan seni tradisi di Indonesia. Menurutnya terdapat tiga seni tradisi di Indonesia, yaitu seni tradisi Ageng, seni tradisi Alit dan seni tradisi suku. Seni-seni tradisi tersebut memiliki fungsi sebagai atraksi wisata, sebagai jati diri komunitas dan sebagai sumber inspirasi untuk penciptaan dan pengembangan seni-seni baru. oleh karenanya, 
seni tradisi tersebut perlu dilestarikan dan dikembangkan. Pelestarian dan pengembangan seni tradisi di Indonesia saat ini terkendala oleh banyak hal. Dalam tulisannya, Ahimsa-Putra menawarkan beberapa alternatif yang dapat dilakukan untuk pelestarian dan pengembangan seni tradisi.

Tulisan kedua ditulis oleh Silvia Delvi, Peneliti Balai Kajian Sejarah Sumatera Barat. Devi dalam artikelnya membahas tentang songket sebagai produk kebudayaan di nagari Pandai Sikek Sumatera Barat. Dalam tulisannya, Delvi lebih menekan pada aspek sejarah dan nilai songket di Pandai Sikek. Menurutnya, Songket Pandai Sikek sudah ada sejak pertengahan abad ke-19. Proses produksi songket Pandai Sikek sangat eksklusif untuk warga Pandai Sikek dan tidak ditransfer kepada orang lain. Hal ini karena terdapat rahasia pembuatan dan nilai pada masing-masing motif yang diproduksi. Jika ingin pandai menenun songket Pandai Sikek, satu-satunya cara adalah dengan menjalin hubungan keluarga dengan orang Pandai Sikek.

Tulisan berikutnya ditulis oleh Meri Erawati, Dosen Sejarah STKIP PGRI Sumbar. Erawati menulis cerita nonton bioskop pada tempo dulu di Kota Padang. Dalam tulisannya, Erawati membahas tentang perkembangan bioskop dan jenis film yang ditayangkan di Kota Padang pada era 1970-2000. Yang menarik dari uraian Erawati adalah cerita tentang bagaimana simbol-simbol muncul di seputaran bioskop dan kecenderungan style orang-orang menonton bioskop pada masa itu. Tidak terkecuali itu, temuan Erawati tentang kejahilan-kejahilan penonton terhadap penonton lainnya memperkaya tulisan Erawati.

Tulisan keempat ditulis oleh Silfia Hanani, dosen Sosiologi IAIN Bukittinggi. Hanani menulis tentang batu akik yang sangat popular dan booming beberapa waktu belakangan. Dalam tulisannya, Hanani menguraikan bagaimana nalar individu dipengaruhi oleh nalar kolektif tentang batu akik, dampaknya semua orang-minimal- memperbincangkan batu akik. Lebih dalam, Hanani juga membahas pemaknaan orang terhadap batu akik yang mengalami pergeseran dari pemaknaan yang sakral ke pemaknaan keindahan dan seni. Masing-masing jenis batu kemudian menjadi identitas bagi penanda bagi daerah asal dimana batu akik ditemukan. Di bagian lain, Hanani juga mendiskusikan paradoks batu akik dengan persoalan kehidupan dan lingkungan.

Tulisan kelima ditulis oleh Faishal Yasin, Dosen Sosiologi STKIP PGRI Sumbar. Tulisan Yasin membahas tentang gaya yang diampilkan oleh remaja di hiburan malam seperti café, bilyar dan diskotik. Secara detail Yasin menguraikan bagaimana para remaja berpakaian, memilih makanan dan musik di masing-masing lokasi hiburan. Yasin kemudian menghubungkan gaya tersebut dengan kultur induk -Minangkabau- dimana remaja tersebut hidup dan berkembang. Dalam analisisnya, Yasin menyebutkan bahwa gaya tersebut merupakan penyimpangan dari kultur induk mereka.

Tulisan keenam ditulis oleh Yusar, dosen Sosiologi Universitas Padjajaran. Yusar menulis perlawawan anak muda terhadap hegemoni radikalisme anak muda di tiga kota di Indonesia. Temuan Yusar, perkembangan tekhnologi dimanfaatkan oleh anak muda secara kreatif dalam melakukan perlawanan terhadap radikalisme agama di tiga kota tersebut. Anak muda menggunakan berbagai media berbasis tekhnologi untuk mengekspresikan perlawanan 
mereka. Ekspresi tersebut anatara lain mereka representasikan melalui meme, pelesetan kata dan lain sebagainya. Dengan baik Yusar kemudian menampilkan berbagai meme dan plesetan kata serta maknanya dalam artikelnya yang cukup panjang.

Tulisan terakhir ditulisn oleh Darmairal Rahmad, dosen sosiologi STKIP PGRI Sumatera Barat. Rahmad menulis integrasi dan interaksi anak muda rantau (kasus mahasiswa) di kawasan kost-kostan kota Padang. Dengan mengambil setting di kawasan Air Tawar Barat, Rahmad menemukan berbagai model dan tipologi interaksi dan ientegrasi anak muda dengan masyarakat di sekitarnya berdasarkan empat pola. Yang menarik dari tulisan Rahmad selain data yang kaya adalah pola penyajian data kualitatif dalam bentuk matrik probabilitas. Sebuah pola yang unik dalam penyajian tulisan kualitatif secara dalam bentuk matrik. Bisa jadi, ini akan menjadi model baru dalam metode penelitian yang kini sedang berkembang, yaitu mixed method.

Demikianlah para penulis telah menymbangkan buah fikiran mereka dalam edisi ini yang tentu saja dapat dibaca secara lebih mendalam pada setiap judul tulisan. Redaksi hanya mengantarkan pembaca pada kulit dari apa yang ditulis oleh para penulisn. Untuk lebih mendalam pada bagian isi, redaksi mengucapkan selamat membaca.

Redaksi 



\section{DAFTAR ISI}

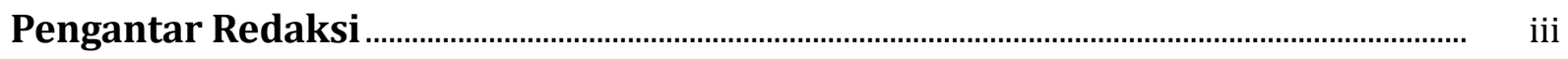

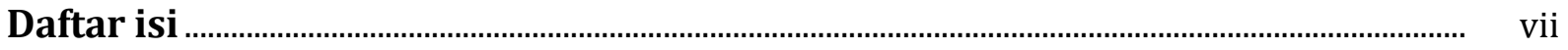

Seni Tradisi, Jatidiri dan Strategi Kebudayaan

Heddy Shri Ahimsa-Putra

Sejarah dan Nilai Songket Pandai Sikek

Silvia Devi

Budaya dalam Lintasan Sejarah: Booming Nonton Bioskop di Padang Tempo Dulu

Meri Erawati.

Paradoksal Gaya Sosial Global; Kajian Budaya dalam Memahami Kesadaran Kolektif di Tengah Booming Batu Akik

Silfia Hanani.

Gaya Kehidupan Malam Remaja di Kota Padang; Suatu Kajian Subkultur di Tempat Hiburan Malam Kota Padang

Faishal Yasin.

Perlawanan Kaum Muda terhadap Hegemoni Radikalisme Agama dalam Bentuk-Bentuk Budaya Populer

Yusar

Gaya Interaksi \& Integrasi Sosial Anak Muda Rantau: Kasus Mahasiswa Kost di Air Tawar Barat, Kota Padang

Darmairal Rahmad.

Profil Penulis 


\title{
SEJARAH DAN NILAI SONGKET PANDAI SIKEK
}

\author{
Silvia Devi \\ silvia160681@gmail.com \\ (Peneliti di Balai Pelestarian Sejarah dan Nilai Tradisional Padang) \\ 一挑-
}

\begin{abstract}
Songket is one of weaving creations produced in various countries in Indonesia. The process of making Songket is not easy. It is a difficult and thorough process and needs a long time. Therefore it requires great care and diligence. One area where artisan Songket come from is Nagari Pandai Sikek (Pandai Sikek village) in West Sumatra. Besides Pandai Sikek, there are some other villages such as Silungkang, Koto Gadang, Kubang, Tanjung Sungayang and Batipuh. But the craft of weaving in Pandai Sikek has existed and developed since 1850. Songket weaving skill in Nagari Pandai Sikek still owned by the older generation to the younger generation. These skills cannot be passed on to generations out of Nagari Pandai Sikek, because this is the message left by the ancestors of village communities. In the process of passing on the skill, they are still using methods that have been taught by their ancestors for hundreds of years ago namely by using handloom (Not Weaving Machine Tools). This paper would like to explain about the history of the birth of weaving Songket of Pandai Sikek, processes and manufacturing techniques and values contained in the motives generated in its weaving Songket.
\end{abstract}

Keyword: Songket, Pandai Sikek, History, Value

Songket merupakan salah satu kreasi tenun yang banyak dihasilkan di berbagai daerah di Indonesia. Proses dalam menghasilkan sebuah tenunan songket tidaklah mudah, melainkan suatu prosesyang rumit, teliti dan membutuhkan waktu yang cukup lama, oleh karenanya dibutuhkan ketelitian serta ketekunan. Salah satu daerah tempat pengrajin kain songket adalah nagari Pandai Sikek di daerah Sumatera Barat. Meskipun tidak hanya di nagari Pandai Sikek, melainkan juga terdapat di beberapa nagari seperti, Silungkang, Koto Gadang, di daerah Kubang, Tanjung Sungayang dan Batipuh. Akan tetapi kerajinan tenun di Pandai Sikek telah ada dan berkembang sejak tahun 1850. Ketrampilan menenun songket di Nagari Pandai Sikek masih dimiliki oleh generasi tua sampai generasi mudanya. Ketrampilan ini tidak bisa diwariskan kepada generasi yang bukan dari daerah Pandai Sikek, karena ini merupakan pesan nenek moyang mereka. 
Dalam proses mewariskan, mereka tetap menggunakan cara-cara yang sudah diajarkan oleh nenek moyang mereka selama ratusan tahun yang lalu, yakni dengan menggunakan Alat Tenun Bukan Mesin (ATBM). Tulisan ini ingin menjelaskan tentang sejarah lahirnya tenunan songket Pandai Sikek, proses dan teknik pembuatannya dan nilai-nilai yang terkandung di dalam motif yang dihasilkan dalam tenun songketnya.

Kata Kunci: Songket, Pandai Sikek, Sejarah, Nilai

\section{PENDAHULUAN}

Berbicara tentang kain untuk pakaian, kita tidak mungkin mengabaikan sifat dan kedudukan manusia sebagai ciptaan Tuhan yang tertinggi derajatnya. Di lain pihak, manusia sebagai mahluk ciptaan Tuhan yang tertinggi derajatnya juga mampu mengembangkan perlengkapan non-ragawi yang dapat mempermudah dirinya dalam menyesuaikan diri dengan lingkungan dimanapun mereka berada. Perlengkapan non-ragawi misalnya adalah senjata, alat dapur dan juga pakaian itu sendiri. Pakaian yang berbentuk kain dihasilkan dengan teknologi dan peralatan tersendiri dari masyarakat yang menghasilkannya seperti di Lampung yang dibuat dengan cara ditenun dan memakai peralatan yang dibuat sendiri, dan kain yang dihasilkannya dikenal dengan sebutan kain tapis. Di Kabupaten Sikka Nusa Tenggara Timur terdapat kain tenun yang juga merupakan pakaian adat disebut kain Lipa Liing. Begitu juga di Sumatera barat yakni di Nagari Pandai Sikek, terdapat kain yang ditenun dengan peralatan sendiri atau dikenal dengan peralatan tradisional tanpa menggunakan Mesin.

Kain untuk pakaian yang dibuat dalam perkembangannya tidak lagi berperan sebagai pelindung dan dekorasi saja, tetapi juga berperan dalam sistem yang hidup dalam masyarakatnya, seperti sistem religi atau upacara kematian, sistem dan organisasi kemasyrakatan. Di Lombok, ada sebagian masyarakatnya yang disebut golongan Islam Telu ${ }^{1}$ (Kartiwa, 1986:12). Mereka sewaktu menjalankan kewajiban agama seperti sembahyang, selalu berpakaian putih dan ikat kepala putih yang disebut dodot ${ }^{2}$. Sedangkan di waktu lain dalam aktivitas sebagai anggota masyarakat mereka memakai pakaian yang berbeda. Sehingga bagi masyarakat Lombok, apabila bertemu dengan orang yang memakai pakaian serba putih sewaktu sembahyang, maka mereka mengetahui bahwa orang tersebut termasuk ke dalam golongan Islam Telu. Dengan demikian pakaian di sini menunjukkan identitas pelakunya.

Masyarakat Indonesia telah mengenal tenunan dengan cara ikat lungsi ${ }^{3}$ (sistem ikat dan kunci) sejak zaman Perunggu atau sekitar abad ke-8 sampai abad ke-2 Sebelum Masehi (Kartiwa, 1989:2). Masyarakat Kalimantan, Sumatera, Sulawesi, dan Nusa Tenggara Timur telah menguasai cara penenunan, menciptakan alat-alat tenun, pewarnaan dengan berbagai jenis getah tanaman. Kala itu, corak kain tenunnya sangat dipengaruhi

1. Salah satu golongan Islam yang hanya melakukan kegiatan keagamaannya sebanyak telu atau tiga kali yakni sembahyang hari Jumat, hari raya Idul Adha dan hari raya Idul Fitri.

2. Dodot dipakai secara khusus oleh para raja atau sultan dan dipakai oleh para penari wanita dalam tari bedoyo katawang. Kecuali untuk para raja dodot seringkali dipakai dalam upacara perkawinan yang dipakai oleh sang pengantin (Kartiwa, 1985:61).

3. Salah satu teknik dalam tenun dimana benang lungsinya (benang yang membujur sepanjang kain dan diletakkan pada dua batang kayu penahab yang merupakan rangka alat tenunan yang disebut Pahikungu di sumba) yang diwarnai dan diikat (Achadji, 1986:3). 
oleh nilai-nilai religius masyarakatnya yang memuja para leluhur dan keagungan alam dan sistem sosialnya. Kain tenun menjadi lambang ikatan solidaritas dan sarana identifikasi bagi setiap masyarakat adat agar selalu menyadari kesamaan asal-usul leluhur mereka. Selain itu coraknya mengandung pesan-pesan moral dan sosial yang dimengerti oleh masyarakat adat daerah itu sendiri.

Daerah-daerah penghasil tenun di Indonesia diantaranya yakni Bali tepatnya di Desa Tenganan Pengrisingan, Kabupaten Karang Asem yang menghasilkan tenun dobel ikat ${ }^{4}$. Kalimantan, Batak, Aceh, Toraja, dan Nusa tenggara adalah penghasil tenunan dengan teknik ikat lungsi. Sulawesi Tengah di daerah Kabupaten Donggala dibuat kain tenun pakan yag menyerupai tenunan yang sama dengan daerah Sulawesi selatan (Kartiwa,1985:46). Menurut Van der Hoop, masyarakat Lampung juga mulai mengenal tenun sejak abad ke -2 Sebelum Masehi yang mana dikenal dengan kain tenun ikat dan kunci (key and Rhombid shape). Sedangkan kerajinan tenun yang menggunakan kapas, telah diperkirakan Roybin dan Jhon Maxel, diperkenalkan oleh musafir dan pedagang asing ke Lampung pada abad ke -7 (Djausal, 2002:12) ${ }^{5}$. Sedangkan tenun songket banyak dihasilkan oleh daerah Sumatera Barat yakni Nagari Pandai Sikek, Silungkang (Kabupaten Sawahlunto) dan tenunan KubangPayakumbuh (Kabupaten Lima Puluh Kota), Sumatera Selatan, Nusa Tenggara Timur, Nusa Tenggara Barat maupun Maluku.

Songket adalah salah satu kreasi tenun yang banyak dihasilkan di berbagai

4. Salah satu teknik tenun dimana benag lungsi dan pakan diwarnai dan diikat, sedangkan jika hanya benang pakan saja yang diwarnai dan diikat disebut ikat pakan (Achadji, 1986:14)

5. Djausal, Anshari. Kain Tapis Lampung, Dinas Pendidikan Propinsi Lampung, Lampung.2002 daerah terutama di Indonesia. Proses dalam menghasilkan sebuah tenunan songket tidaklah mudah, melainkan suatu proses yang rumit, teliti dan membutuhkan waktu yang cukup lama, oleh karenanya dibutuhkan ketelitian serta ketekunan seperti yang diungkapkan oleh Bart dalam Revitalisasi Songket Lama Minangkabau (2006:17). Songket yang merupakan salah satu pakaian yang dikenakan oleh manusia merupakan salah satu karya seni yang indah, karena fungsinya tidak hanya bersifat sebagai pelindung, dekorasi, melainkan untuk menonjolkan suatu tujuan dengan daya tariknya (Kartiwa, 1986:4). Salah satu fungsi pakaian yakni untuk menonjolkan daya tariknya, maka dalam hal ini dapat dilihat pada kemewahan dan kilauan songket dari warnawarni benang yang digunakan baik itu dengan benang emas maupun dengan benang-benang hasil celupan pewarnaan dari keahlian para penenunnya.

Pandai Sikek adalah Nagari di Kabupaten Tanah Datar, Provinsi Sumatera Barat yang sampai hari ini masih memproduksi songket secara turun temurun. Produk kerajinan tenun songket Pandai Sikek tidak hanya terbatas pada berbagai macam pakaian seperti baju kurung dan destar, tetapi juga berbagai kelengkapan upacara adat dan perkawinan, seperti: kodek songket, saruang balapak, saruang batabua, selendang songket atau selendang batabua tingkuluak tanduak (tutup kepala wanita), dan sisampiang (salempang yang biasa digunakan penghulu). Songket bagi masyarakat Minangkabau merupakan jenis pakaian yang tinggi nilainya (sangat dihargai). Oleh karena itu, pemakaiannya terbatas pada peristiwa-peristiwa atau kegiatan-kegiatan tertentu, seperti: perkawinan, batagak gala (penobatan penghulu), dan penyambutan tamu-tamu penting. 
Berkembangnya kerajinan tenun songket di Sumatera Barat tidak berlangsung lama, hal ini dikarenakan adanya penindasan yang dilakukan oleh kolonial Belanda pada kaum Paderi tahun 1837. semenjak itu masyarakat mengalami kesulitan dalam memperoleh kapas sebagai bahan mentah dalam proses pembuatan tenun songket. Seperti yang ditulis oleh Hasselt (Oki, 1979) diungkapkan oleh salah seorang pejabat Belanda pada tahun 1870-an bahwa pada tahun 1820-an suara alat tenun dapat terdengar di setiap penjuru Sumatera Barat, akan tetapi semenjak tahun 1870-an suara itu sudah tidak terdengar lagi.

Keterpurukan itu terus berlanjut pada saat penjajahan Jepang yakni dari tahun 19421945, sampai-sampai masyarakat di nagarinagari di Sumatera Barat termasuk Nagari Pandai Sikek harus menyimpan alat tenun yang telah lama mereka pakai yang merupakan warisan nenek moyang dikarenakan sulitnya mencari benang. Seperti yang diungkapkan oleh salah seorang informan yakni Hj. Sanuar ${ }^{6}$ yang mengatakan bahwa biasanya mereka menggunakan benang emas yang diimpor dari Macao, Cina dan benang sutra dari luar daerah, tapi sejak penjajahan Jepang mereka tidak mendapatkan kiriman lagi. Konon kabarnya pabrik benang emas di Macao hancur akibat Perang Dunia ke II. Karena pada masa itu merupakan masa penjajahan, dimana keselamatan jiwa dan raga sangat dipentingkan demi merebut kemerdekaan, maka pada saat itu kegiatan menenun tidak dapat dilakukan.

6. Salah seorang informan yang bernama Hj.Sanuar yang akrab dipanggil dengan nenek Nuan, berusia 83 tahun yang memiliki pekerjaan sebagai pengusaha tenun pada galeri Pusako beralamat di Jorong Baruah, Pandai sikek. Lihat Chrisyawaty, Eny dan Ernatip, Kontinuitas Pola Pewarisan seni Menenun Songket di Nagari Pandai Sikek $X$ Koto Tanah datar, Balai Pelestarian Sejarah dan Nilai Tradisional Padang, 2009.
Meskipun sudah mengalami pasang surut keterampilan menenun songket di Nagari Pandai Sikek masih dimiliki masyarakat nagari mulai dari generasi tua sampai pada generasi muda sekarang ini. Diketahui bahwa ketrampilan ini tidak bisa diwariskan kepada generasi yang bukan dari daerah Pandai Sikek, karena ini merupakan pesan nenek moyang masyarakat nagari itu. Dalam proses mewariskan, mereka tetap menggunakan cara-cara yang sudah diajarkan oleh nenek moyang mereka selama ratusan tahun yang lalu, yakni dengan menggunakan ATBM (Alat Tenun Bukan Mesin). ATBM ini tidak terlindas oleh roda zaman yang sekarang ini sudah menggunakan teknologi mesin, oleh karena itu menenun dengan menggunakan ATBM tidak semudah menggunakan mesin, di sini diperlukan kesabaran, kecermatan yang tinggi dan pastinya dengan waktu yang tidak singkat. Tidak salah kiranya kalau harga sehelai tenunan songket begitu mahal harganya, karena disebabkan hal di atas, selain itu dikarenakan benang yang merupakan bahan dasar pembuat tenunan harganya mahal dan masih harus diimpor.

Berangkat dari uraian di atas mengenai warisan menenun songket yang merupakan salah satu warisan yang tak ternilai harganya, maka dalam tulisan ini akan digali lebih lanjut mengenai sejarah lahirnya tenunan songket Pandai Sikek, proses dan teknik pembuatannya dan nilai-nilai yang terkandung di dalam motif yang dihasilkan dalam sebuah tenun songket tersebut.

\section{SEJARAH TENUN SONGKET PANDAI SIKEK}

Sejarah tenun di Indonesia menurut Murnayati (1991:7), terdapat beberapa pendapat, pertama yakni menurut Effendi, 
dikatakan bahwa para antropolog sebelumnya telah memperkirakan bahwa Kebudayaan menenun berasal dari Mesopotamia dan Mesir, kemudian disebarkan ke Eropa dan Asia termasuk di dalamnya Indonesia (1988:1). Pendapat kedua menurut ahli sejarah Robyn dan John Maxweel mengatakan bahwa tradisi tenun songket dan sutera dibawa oleh para pedagang Islam yang berasal dari Arab dan India yang menguasai perdagangan di Asia Tenggara, kegiatan berdagang dilakukan sambil menyebarkan agama Islam yang dilakukan pada saat perjalanan dari Selat Malaka menuju pelabuhan-pelabuhan Sumatera dan Pantai Utara Jawa (Kartiwa, 1986:5). Pendapat ke tiga, dikatakan bahwa tenunan berasal dari daerah penghasil kerajinan yang membuat motif-motif tersebut dari kebiasaan hidup sehari-hari dimana songket itu tumbuh dan berkembang (Kartiwa, 1982:12). Oleh karena itu di masing-masing daerah penghasil tenun itu terdapat nama-nama khas dari kain tenun yang dihasilkan.

Salah satunya seperti yang ditulis oleh Ernatip (2009:16) di daerah Palembang kata songket berasal dari kata disongsong dan diteket. Kata teket itu sendiri dalam bahasa Palembang lama berarti sulam. Pendapat lain mengatakan bahwa kata songket berasal dari songko yang berarti kain penutup kepala yang dihias benang emas. Benang emas yang dipakai pada hiasan kepala itu juga dipakai pada kain tenun.

Banyak istilah lain dari kain songket yang sesuai dengan nama asal daerahnya antara lain Daerah Istimewa Aceh disebut Ija kasap, di Sulawesi Tengah subi kumbaja atau subi sabe, di Sumbawa disebut selungkang. Di dalam penggunaan istilah songket ini banyak dirinci macam-macam bentuk desain yang tampak menurut teknik pembuatannya.
Kain songket Aceh pada umumnya banyak berlatar sutra hitam, biru tua, ungu, merah tua, dan warna lainnya. Kain sarungnya disebut ija krung, kain panjang atau selendang panjang disebut ija dua blah hah. Kain songket dari Minangkabau berbeda daya coraknya dengan songket dari Aceh. Kain songket Balapak yaitu kain songket dengan desain benang emas atau perak yang memenuhi seluruh permukaan kain. Kain songket batabua atau bertabur, dimana desain benang emas atau benang perak dengan motif tersebar disebut juga songket babintang.

Kerajinan tenun songket yang terdapat di Sumatera Barat tidak hanya terdapat di Nagari Pandai Sikek, melainkan terdapat di beberapa daerah seperti, Silungkang, Koto Gadang, di daerah Kubang, Tanjung Sungayang dan Batipuh. Akan tetapi menurut tulisan Jasper dan Mas Pirngadie dalam buku De Islandsche Kunstryverheid in Nederlandech Indie Deel II pada tahun 1912 pusat kerajinan tenun di Minangkabau antara lain terdapat di Pandai Sikek. Sesuai dengan tulisan itu kerajinan tenun di Pandai Sikek telah ada dan berkembang sejak tahun 1850.

Akan tetapi menurut tabloid Suara Silungkang Edisi ke 5, November 2007 tenun songket yang merupakan seni budaya spesifik benua Asia ini berasal dari daratan negeri Cina, keberadaannya lebih kurang sejak 1000 tahun yang lalu. Dalam kisah perjalanan yang cukup panjang. Tenun Songket setelah itu hadir di Negeri Siam (Thailand), kemudian menyebar ke beberapa negara bagian di Semenanjung Negeri Jiran Malaysia. Seperti ke Selangor, Kelantan, Trengganu dan Brunai Darussalam kemudian menyeberang ke pulau Andalas yaitu ke Silungkang, Siak dan Palembang. Yang mana Songket Silungkang berasal dari Negara Bagian Selangor, sedangkan Songket Pandai 
Sikek berasal dari Silungkang dan Songket Payakumbuh berasal dari Pandai Sikek. Yang membawa ilmu songket dari Selangor ke Silungkang yaitu Baginda Ali asal Kampung Dalimo Singkek beserta hulubalang beliau yang diperkirakan pada abad ke 16 dan lebih kurang sudah sejak 400 tahun yang lalu.

Dalam literatur lain Christyawaty (2009:68) mengungkapkan mengenai sejarah tenun di Sumatera Barat yakni berdasarkan tulisan Daghregister (Oki; 1979) dikatakan bahwa walaupun sulit untuk mencari sejarah yang pasti mengenai sejarah kerajinan menenun, akan tetapi dapat dibuktikan terdapat lahan yang ditanami kapas di Indrapura pada laporan tahun 1665, tepatnya di "Bandar Sepuluh" dan Sungai Pagu. Hasil dari tanamam kapas tersebut kemudian disebarkan melalui Koto Tengah di sebelah Utara kota Padang menuju pelosok Minangkabau. Akan tetapi karena pada masa itu merupakan masa penjajahan Belanda dan mereka tidak menginginkan kemakmuran rakyat Sumatera Barat, maka mereka melarang adanya penanaman kapas di ranah Minang pada sekitar tahun 1660-an.

Seperti yang diungkapkan oleh Dobbin bahwa pada sekitar tahun 1780-an untuk mengurangi ketergantungan akan bahan mentah untuk kegiatan menenun tersebut maka digerakkanlah masyarakat khususnya di daerah Agam dan Limapuluh Kota untuk menanam kapas karena ini pada akhirnya akan membawa kemakmuran pada masyarakat. Gerakan ini disebabkan oleh dua faktor penting yakni : pertama, adanya penyusupan Inggris ke Sumatera Barat sejak pertengahan abad XVIII yang menyebabkan masyarakat dapat membelinya dengan harga murah daripada harga yang ditetapkan oleh Belanda. Faktor

7. Merupakan pelabuhan yang terletak di daerah pesisir antara Painan dan Indrapura. kedua, yakni adaya perluasan perdagangan di dataran tinggi Sumatera Barat pada tahun 1870-an yakni dibukanya Penang di Semenanjung Malaya yang berdampak meningkatnya permintaan terhadap produksi tenun (Oki, 1979).

Tidak seluruh masyarakat Minangkabau yang bertahan dalam keterpurukan keadaan pada masa itu. Oleh seorang tokoh masyarakat yakni wali nagari pada masa itu di tahun 1960an yang bernama Ahmad Ramli Dt. Rangkayo Sati yang memiliki latar belakang seni lukis dan ukir membangun tempat atau workshop ukiran tradisional minang dan juga tenunan songket dengan dibantu oleh Hj.Sanuar. Usaha kerajinan terus berkembang, ditambah lagi adanya proyek pembuatan ukiran sejumlah perkantoran pemerintah yang beratap gonjong yang diberikan oleh Gubernur Sumatera Barat yakni Kaharuddin Dt. Rangkayo Basa. Proyek tersebut banyak menyerap tenaga pengrajin karena setelah proyek itu selesai, Ramli bersama Sanuar fokus mengembangkan usaha galeri songket yang dinamakan "Rumah Tenun Pusako". Berkat usaha mereka yang mempekerjakan banyak pengrajin maka Pandai Sikek berubah menjadi salah satu daerah tujuan wisata ${ }^{8}$ untuk belanja hasil kerajinan yang hampir setiap harinya dikunjungi oleh para wisatawan sampai hari ini.

Keberlangsungan dari kerajinan tenun songket Pandai Sikek ini terwujud dikarenakan adanya proses pewarisan yang terus berlangsung. Pewarisan tersebut dilakukan hanya dalam satu garis keturunan, seperti pewarisan yang dilakukan seorang nenek kepada cucunya, seorang ibu kepada anak gadisnya demikian seterusnya. Ruang lingkup pewarisan tidak boleh keluar dari

8. Kini Daerah Tujuan Wisata lebih dikenal dengan sebutan destinasi 
garis keturunan yang lebih dikenal dengan sebutan saparuik. ${ }^{9}$ Tidak hanya itu, dalam falsafah kehidupan perempuan khususnya di Nagari Pandai Sikek harus tahu dengan kato nan ampek, ${ }^{10}$ yakni tahu jo takok baniah, tahu jo suduik kampia, tahu jo liang karok, tahu jo atah takunyah.

Terdapat satu aturan atau sumpah dalam proses pewarisan bertenun songket yang diyakini oleh masyarakat Nagari Pandai Sikek, yakni bahwa kepandaian bertenun hanya boleh diwariskan kepada anak cucu yang berasal dari rumah gadang, seandainya sumpah itu dilanggar maka hidup mereka bak " $k a$ bawah indak baurek, ka ateh indah bapucuak, di tangah-tangah digiriak kumbang, yang artinya bagi yang melanggar sumpah maka hidupnya akan sengsara seumur hidup.

Sesuai dengan konvensi adat yang berlaku di Nagari Pandai Sikek mengenai siapa saja yang berhak memiliki ketrampilan menenun adalah seperti yang diungkapkan oleh Christyawati (2009:76), yakni :

9. Saparuik berasal dari satu paruik seorang niniek/gaek yang sama dan masih merupakan bagian dari suku yang sama. Tingkatan yang lebih atas dari saparuik adalah sajurai yakni orang-orang yang berasal dari satu perut seorang nenek yang menempati satu rumah gadang. Tingkatan yang pertama yakni samandeh atau sarumah dimana anak-anak yang lahir dari seorang ibu. Jadi dalam masyarakat minangkabau menganut sistem matrilineal yang melihat garis keturunan dari garis ibu. Lihat lebih lengkap di Amir MS (1997:51)

10.Secara umum kato nan ampek yang diketahui oleh masyarakat, yakni kato mandaki, kato malereng, kato manurun dan kato mandata. Namun kato nan ampek dalam hal ini adalah sebuah penekanan identitas seorang perempuan Pandai Sikek. Adapun arti dari kato nan ampek di atas, yakni seorang perempuan Pandai Sikek diharapkan pandai dalam bertanam padi, pandai menganyam, pandai bertenun, dan pandai memasak. Adanya kepandaian yang diharapkan dimiliki oleh para perempuan Pandai Sikek di atas adalah bertujuan sebagai bekal kelak nanti manakala sudah berumah tangga. Karena dengan kepandaian tersebut maka seorang perempuan dapat menjadi seorang istri yang tahu akan kewajibannya dan juga dapat membantu perekonomian keluarga, salah satunya yakni kepandaian menenun yang dapat menghasilkan uang. a. Orang asli atau penduduk asli Nagari Pandai Sikek, artinya nenek moyangnya atau ninik mamaknya berasal dari nagari ini.

b. Orang yang sudah menetap lama dan sudah menjadi warga Nagari Pandai Sikek (malakok).

c. Orang yang menikah dengan warga asli Nagari Pandai Sikek.

\section{PERALATAN PEMBUATAN TENUN SONGKET}

Bahan dasar kain tenun songket adalah benang tenun yang disebut benang lusi atau lungsin. Benang tersebut satuan ukurannya disebut palu. Sedangkan, hiasannya (songketnya) yang berupa benang emas atau benang perak menggunakan benang Makao atau benang India. Benang yang satuan ukurannya disebut pak ini didatangkan dari Singapura melalui Tanjung Pinang. Peralatan tenun songket Pandai Sikek terbagi menjadi dua, yakni peralatan pokok dan tambahan. Peralatan pokok adalah peralatan yang wajib ada dalam proses pembuatan tenun songket karena ini digunakan untuk membuat dasar kain songket, sedangkan peralatan tambahan digunakan sesuai dengan keperluan pembuatan beberapa jenis motif dan berguna untuk memperlancar kegiatan produksi tenun. Keduanya terbuat secara tradisional dengan berbahan dari kayu dan bambu (lihat lebih lengkap dalam Murnayati (1991:38-41) dan Christyawaty dan Ernatip (2009:36-42). Yang merupakan peralatan pokok adalah :

1. Panta yakni sebuah tempat duduk bagi penenun yang terbuat dari kayu menyerupai bangku panjang. Kata panta berasal dari kata palanta yang berarti balai tempat duduk.

2. Paso yaitu alat penggulung kain yang telah ditenun akan tetapi belum dipotong 
dari benang pembuat dasar kain, paso ini berbentuk bulat panjang yang terbuat dari kayu.

3. Suri yaitu kawat yang agak kasar dan kuat disusun rapat, alat ini tergantung pada tali karok. Pada setiap benang yang terentang di alat tenun akan melalui susunan kawat ini satu persatu.

4. Karok alat yang mirip dengan suri hanya saja terbuat dari benang nilon. Setiap benang terentang untuk disusun harus melalui karok ini. Karok terdiri dari dua macam, yakni sebagai pengatur benang lungsi yang dibawah dan pengatur benang lungsi yang di atas.

5. Penggulung benang yakni kayu berbentuk bulat dan memanjang di depan alat tenun, berfungsi sebagai penggulung benang yang terentang untuk ditenun.

6. Arang babi sebagai penyangga penggulung benang yang belum ditenun

7. Kaminggang yakni alat berupa penyangga panta dan bersambungan dengan arang babi.

8. Tijak-tijakadalahalatyangcarapenggunaannya diinjak oleh kaki si penenun berfungsi untuk merapatkan atau mengencangkan helai-helai benang ketika membuat motif.

9. Atua kawa yakni tempat masuknya karok.

10. Kudo-kudo adalah alatyang digunakan untuk mengikatkan karok guna mempermudah proses menaik turunkan benang.

11. Tandayan adalah tali karok.

12. Langan-langan yakni tempat bergantungnya tali karok dan tali suri yang terbuat dari kayu.

13. Pakan yakni benang yang terentang pada alat tenun yang menjadi dasar dari kain songket.

14. Palapah alat yang terbuat dari bambu yang salah satu ujungnya diruncingkan. Berfungsi untuk menyangga kain yang telah dijungkit, kemudian dimasukkan lidi sebelum disangga yang sesuai dengan motif yang dibentuk.

15. Pancukia adalah alat yang digunakan untuk mengatur motif.

16. Sangka yakni penyangga kain yang sudah ditenun, terletak di bawah paso.

17. Lidi adalah alat yang berfungsi untuk membuat dan mengatur motif.

18. Turak adalah alat yang terbuat dari sepotong bambu yang dipotong dan diberi lubang di tengahnya, sebagai alat bantu untuk memindahkan benang dari sisi satu ke sisi lainnya.

19. Kasali berfungsi sebagai penggulung benang pembuat motif dan benang tambahan yang selanjutnya dimasukkan ke dalam turak.

20. Tungau berfungsi sama dengan turak, tetapi di pakai pada waktu menenun songket batabua.

Adapun alat yang merupakan alat tambahan dalam proses pembuatan tenunan yaitu :

1. Kincia yakni alat yang digunakan untuk menggulung benang.

2. Ulang-aliang yakni alat untuk merentangkan benang yang akan digulung.

3. Palapah bayam yakni alat untuk meluruskan benang-benang kusut.

4. Daluang yakni alat yang digunakan untuk meletakkan lidi-lidi.

Sebagai catatan, di masa lalu jika pengrajin menginginkan suatu warna tertentu, maka benang yang akan diwarnai itu dicelupkan ke air panas (mendidih) yang telah diberi warna tertentu, kemudian dijemur. Di masa kini hanya sebagian yang masih melakukannya. Sebagian lainnya langsung membeli benangwarna yang telah diproduksi oleh suatu pabrik. 


\section{TEKNIK PEMBUATAN TENUN SONGKET}

Pembuatan tenun songket dilakukan dalam dua tahap. Tahap pertama adalah penenunan kain dasar dengan konstruksi tenunan rata atau polos. Caranya benangbenang yang akan dijadikan kain dasar (ditenun) dihubungkan ke paso. Posisi benang yang membujur ini oleh masyarakat Pandai Sikek disebut "benang tagak". Setelah itu, benang-benang tersebut direnggangkan dengan alat yang disebut palapah.

Pada waktu memasukkan benangbenang yang arahnya melintang, benang tagak direnggangkan dengan alat yang disebut palapah. Pemasukkan benang-benang yang arahnya melintang ini menjadi relatif mudah karena masih dibantu dengan pancukia dengan hitungan tertentu menurut motif yang akan dibuat. Setelah itu, pengrajin menggerakkan karok dengan menginjak salah satu tijak-panta untuk memisahkan benang sedemikian rupa, sehingga ketika benang pakan yang digulung pada kasali yang terdapat dalam skoci atau turak dapat dimasukkan dengan mudah, baik dari arah kiri ke kanan (melewati seluruh bidang karok) maupun dari kanan ke kiri (secara bergantian). Benang yang posisinya melintang itu ketika dirapatkan dengan karok yang bersuri akan membentuk kain dasar.

Tahap kedua adalah pembuatan ragam hias dengan benang emas. Caranya agak rumit karena untuk memasukkannya ke dalam kain dasar mesti melalui perhitungan yang teliti. Dalam hal ini bagian-bagian yang menggunakan benang lusi ditentukan dengan alat yang disebut pancukie yang terbuat dari bambu. Konon, pekerjaan ini memakan waktu yang cukup lama karena benang lusi/lungsin itu harus dihitung satu persatu dari pinggir kanan kain hingga pinggir kiri menurut hitungan tertentu sesuai dengan contoh motif yang akan dibuat. Setelah jalur benang emas itu dibuat dengan pancukie, maka ruang untuk meletakkan turak itu diperbesar dengan alat yang disebut palapah. Selanjutnya, benang emas tersebut dirapatkan satu demi satu, sehingga membentuk ragam hias yang diinginkan.

Sedangkan Christyawaty dan Ernatip (2009: 42-43) membagi proses pembuatan tenun menjadi tiga tahap, yakni tahap persiapan yaitu menyiapkan seluruh benang yang akan digunakan sesuai dengan motif yang akan dibuat, tahap pengerjaan sampai pada tahap terakhir yakni tahap penyelesaian. Lama tidaknya pembuatan suatu tenun songket, selain bergantung jenis pakaian yang dibuat dan ukurannya, juga kehalusan dan kerumitan motif songketnya. Semakin halus dan rumit motif songketnya, akan semakin lama pengerjaannya. Pembuatan sarung dan atau kain misalnya, bisa memerlukan waktu kurang lebih satu bulan. Bahkan, seringkali lebih dari satu bulan karena setiap harinya seorang pengrajin rata-rata hanya dapat menyelesaikan kain sepanjang 5-10 cm.

Dalam pemeliharaan kain songket tidak boleh dilipat akan tetapi digulung dengan kayu bulat yang berdiameter $5 \mathrm{~cm}$. Hal ini bertujuan untuk menjaga agar bentuk motifnya tetap bagus dan benang emas-nya tidak putus, sehingga songketnya tetap dalam keadaan baik dan rapi dan bertahan lama.

\section{MOTIF RAGAM HIAS TENUN SONGKET}

Beberapa nagari yang terkenal sekali dengan kain tenunya dan sangat produktif pada masa itu adalah Koto Gadang, Sungayang, dan Pitalah di Batipuh, dan nagari yang melanjutkan tradisi warisan menenun hari 
ini adalah nagari yang termasuk Nagari Batipuh Sapuluh Koto juga Nagari Pandai Sikek. Motif-motif kain tenun Pandai Sikek selalu diambil dari contoh kain-kain tua yang masih tersimpan dengan baik dan sering dipakai sebagai pakaian pada upacara-upacara adat dan untuk fungsi lain dalam lingkup acara adat, misalnya sebagai tando, dan dipajang juga pada waktu batagak rumah. Motif-motif tenun Pandai Sikek diyakini sebagai motif asli pada kain-kain tenunan wanita Pandai Sikek pada zaman lampau, yang namanya sebagian masih diingat oleh beberapa orang tua yang hidup sekarang. Diantara nama mereka adalah: Sari Bentan, Namun, Salamah di Baruah Nuriah. Ipah, Pasah, Nyiah dan Jalisah di Tanjung. Ada kira-kira sepuluh orang master tenun di Pandai Sikek pada zaman atau generasi nama-nama di atas, kira-kira seratus tahun yang lalu. Ada juga beberapa wanita Pandai Sikek zaman dahulu yang dikenal dengan nama julukan yang berhubungan dengan peralatan tenun. Misalnya, dikenal Inyiak Makau dan Inyiak Suri di Tanjuang. Di Koto Tinggi, Inyiak Banang, dan Inyiak Karok. Disamping itu, Pandai Sikek sebagai pusat di bidang tenun songket waktu itu, tentu wanita-wanitanya sering mengerjakan pesanan dari daerah-daerah lain, seperti dari Pitalah di Batipuah, Koto Gadang di Agam dan dari Sungayang dengan corak benang dan motif yang spesifik dengan daerah tersebut, dan dikenal sampai sekarang sebagai motif-motif Sungayang, motif Koto Gadang. Motif ragam hias pada tenunan Pandai Sikek banyak macamnya. Terdapat 90 (Sembilan puluh) motif yang telah terinventarisasi oleh Jasper (Murnayati,1991:44).

Pada dasarnya motif-motif yang terdapat dalam tenun songket Pandai Sikek adalah cukie dan sungayang. Cukie adalah sebuah pola yang mengisi bagian-bagian dari kain.
Misalnya, cukie untuk badan kain, cukie untuk kepala kain, cukie untuk tapi atau pola pinggir kain, dan cukie untuk biteh yang membatasi antarbeberapa motif (cukie). Nama-nama cukie tersebut pada umumnya dicontoh dari kainkain tua yang masih tersimpan dengan baik dan hanya digunakan pada saat ada upacara adat, diantaranya adalah: cukie barantai, cukie bakaluak, cukie bungo tanjung, cukie kaluak paku, cukie barayam pucuak rabuang, cukie barayam tali-tali burung, cukie kaluak, lintadu bapatah, cukie bugis barantai, cukie bungo batang padi, ula gerang, cukie basisiak batali burung, cukie kaluak bungo sikakau, cukie bareh randang, arai pinang baakar cino, pucuak rabuang bajari, cukie pucuak rabuang bungo sikakakau, cukie bugis batali, cukie bungo sitaba, cukie batang padi, lintadu bararak, cukie kaluak babungo, cukie tapak manggis batali, cukie barayam talang-talang, cukie ulek sipadiah, tupuak manggis barantai, itik pulang patang, bijo antimun dan bungo tanjuang, tali burung, talue burung, cukie kaluak ampek puluah, cukie barakar, ayam tadie ilalang, cukie baayam baakar, cukie basisiak batang pinang, bareh randang dan biku-biku.

Sedangkan Sungayang adalah corak keseluruhan kain tenun atau songket. Namanama motif Sungayang diantaranya adalah: Saik Kalamai, Buah Palo, Balah Kacang, Barantai Putiah, Barantai Merah, Tampuak Manggih, Salapah, Kunang-kunang, Api-api, Cukie Baserak, Sirangkak, Simasam, dan Silala Rabah.

\section{NILAI YANG TERKANDUNG DALAM TENUN SONGKET}

Tenun Songket Pandai Sikek jika dicermati, di dalamnya mengandung nilainilai yang pada gilirannya dapat dijadikan 
sebagai acuan dalam kehidupan sehari-hari bagi masyarakat pendukungnya. Nilai-nilai itu antara lain: kesakralan, keindahan (seni), ketekunan, ketelitian, dan kesabaran.

Nilai kesakralan tercermin terlihat dari aturan pemakaian kain songket yang tidak bisa sembarang di pakai. Ada waktu-waktu dalam upacara-upacara tertentu untuk memakainya. Contohnya pada acara perkawinan dan batagak gala (penobatan penghulu). Jika ada seseorang yang menggunakan tenun secara sembarangan, maka ia telah melanggar nilai kesakralan, dan terhadap orang tersebut akan dicemooh oleh masyarakat yang melihatnya

Nilai keindahan terpancar dari indahnya motif ragam hias dari kain tersebut. Keindahan tersebut menggambarkan nilai seni yang indah yang apabila dibuat dengan sehalus mungkin akan semakin indah terpancar motifnya. Berbekal keindahan kain tenun tersebut, maka seorang yang memakai kain akan semakin terlihat cantik dan anggun yang dipancarkan dari keindahan kain tenun tersebut.

Nilai ketekunan, ketelitian, dan kesabaran tergambar dari lamanya proses membuat sehelai kain, seperti yang dikatakan di atas tadi bahwa terkadang seharinya hanya mampu membuat 5-10 cm. Tenunan tidak dapat dibuat pada saat si penenun dalam keadaan emosi karena menenun adalah kegiatan yang harus dilakukan dengan sabar dan teliti. Kalau hati sedang emosi maka biasanya benang yang akan ditenun akan kusut. Seperti juga melakukan pekerjaan lain yang harus ditekuni dengan sabar agar pekerjaan berhasil dengan baik.

\section{KESIMPULAN}

Songket adalah salah satu kreasi tenun yang banyak dihasilkan di berbagai daerah terutama di Indonesia. Proses dalam menghasilkan sebuah tenunan songket tidaklah mudah, melainkan suatu proses yang rumit, teliti dan membutuhkan waktu yang cukup lama, oleh karenanya dibutuhkan ketelitian serta ketekunan. Salah satu daerah tempat pengrajin kain songket di daerah Sumatera Barat, adalah Pandai Sikek. Sebagai kekayaan budaya yang bernilai tinggi, maka wajiblah kita untuk terus melestarikannya meskipun zaman terus mengalami perubahan. Karena songket dengan motifnya adalah gambaran nilai-nilai falsafahyang tinggi yang dianut oleh masyarakat Nagari Pandai Sikek khususnya dan Sumatera Barat pada umumnya.

\section{DAFTAR PUSTAKA}

Bart, Bernhard, 2006. Revitalisasi Songket Lama Minangkabau, Studio Songket Erika Rianti, Padang.

Christyawaty, Eny, dan Ernatip, 2009. Kontinuitas Pola Pewarisan Seni Menenun Songket di Nagari Pandai Sikek, X Koto, Tanah Datar, Depbudpar, Balai Pelestarian sejarah dan Nilai Tradisional Padang.

Devi, Silvia, 2004. Makna Motif Kain Tapis Krui Studi tentang Makna Motif Kain Tapis Krui di Kecamatan Teluk Betung Utara, Kotamadya Bandar Lampung, Propinsi Lampung, Skripsi S1 Jurusan Antropologi, FISIP Universitas Andalas, Padang.

Ernatip, 2009. Inventarisasi Tenun Tradisional Songket Palembang, Depbudpar, Dijend NBSF, Direktorat Tradisi.

http://www.tenun-pusako.com.

http://www.pandaisikek.net Is Sikumbang on July 18, 2008.Sejarah Songket Pandai Sikek 
http://eriassumarna.blogspot.com/ Jakarta 17 Juni 2009 Membuka Cakrawala Indonesia

http://www.pelita.or.id, Sumber: Drs Widodo (Museum Nasional/ Proyek Pengembangan Kebijakan Kebudayaan),

http://www.yfred.wordpress.com. Sejarah kain Tradisional Indonesia. Sri Astutik (11 Desember 2009)

Kartiwa, Suwati, Songket Indonesia, Depdikbud, Dirjenbud, Museum Nasional, Jakarta, 1982.

MS. Amir, 1997. Adat Minangkabau : Pola Tujuan Hidup Orang Minang. Jakarta : Citra Harta Prima.
Murnayati, Aurora, 1991. Arti Simbolis motif Songket Minangkabau Kasus: Kain Songket, Kabupaten Pandai Sikek Kecamatan X Koto, Kabupaten Tanah Datar. Skripsi S1 Fakultas Sastra, Universitas Andalas, Padang.

Oki, Akira, 1986. Catatan Mengenai Sejarah Industri Tekstil di Sumatera Barat, Artikel dalam Indonesia dalam Kajian Sarjana Jepang,(Ed.Akira Nagazumi), Yayasan Obor, Jakarta. 


\title{
PANDUAN PENULISAN
}

\author{
Jurnal Mamangan Edisi III, Program Studi Pendidikan Sosiologi \\ STKIP PGRI Sumatera Barat
}

\section{a. Pendahuluan}

Setiap tulisan ilmiah, baik berupa essay, makalah, jurnal, laporan penelitian dan buku memiliki karakteristik tersendiri sesuai dengan selera penulis, penerbit, sponsor penelitian dan atau aturan-aturan tertentu sesuai dengan ruang dan waktu dimana tulisan dibuat oleh penulis. Selain itu, karakteristik sebuah tulisan ilmiah juga menggambarkan karakter institusi dimana sebuah tulisan diterbitkan. Meskipun demikian sebuah tulisan ilmiah tentulah memiliki standar minimum yang harus dipenuhi. Standar minimum tersebut terkait dengan substansi isi dan aspek teknis dalam penulisannya. Dengan dua standar yang ada sebuah tulisan ilmiah dapat dipertanggungjawabkan secara akademis.

Mengikuti logika umum penulisan ilmiah, ragam bentuk dan karakteristik tulisan ilmiah yang berlaku umum dalam khasanah akademik maupun praktis sebagaimana diuraikan di atas, untuk menjadikan Jurnal Mamangan sebagai sebuah karya ilmiah, program studi sosiologi juga menginginkan jurnal Mamangan memiliki karakter yang kuat dan spesifik dalam kerangka isu dan bentuk penulisan. Karakter dan spesifikasi yang kuat antara lain dapat diatur melalui dua hal, pertama substansi isi. Substansi isi diatur melalui tema dan isu utama tulisan pada masing-masing edisi jurnal yang ditetapkan oleh redaksi. Paling tidak, tulisan yang ada dalam satu edisi memiliki isu utama yang sama dalam kacamata disiplin ilmu yang berbeda, sehingga jurnal melahirkan pembahasan isu dengan multiparadigma. Dengan khasanah ilmu yang berbeda tersebut kemudian isu utama jurnal pada masing-masing edisi akan memiliki perspektif yang banyak dan isu utama dapat dibahas secara utuh dan kokoh.

Kedua pengaturan teknis dan sistematika penulisan. Pengaturan teknis dan sistematika penulisan bertujuan untuk menyamakan pola dan kerangka penulisan yang hendak dimuat dalam jurnal. Pengaturan teknis dan sistematika penulisan ini sekaligus bertujuan untuk membantu penulis dalam mengerangkakan tulisan ilmiah yang akan dikirimkan ke Jurnal Mamangan Diharapkan dengan pengaturan format makalah secara substansi dan teknis, jurnal Mamangan memiliki karakter yang kuat dan khas dalam secara ilmiah.

\section{b. Tujuan}

Pengaturan teknis dan format penulisan ini tidak berpretensi untuk menggurui atau bahkan mengajarkan kepada partisipan tentang bagaimana cara menulis ilmiah yang baik dan benar, tapi pengaturan format ini tidak labih dari sekedar menyamakan persepsi tentang substansi dan format tulisan yang diinginkan dalam jurnal yang direncanakan. Sehingga, penulisan panduan ini hanya sebatas untuk menyamakan pola dan kerangka dasar penulisan untuk tema yang sama dalam kacamata yang berbeda.

\section{c. Teknis dan Format Penulisan}

1. Naskah merupakan karya ilmiah original penulis dan tidak mengandung unsur plagiarisme;

2. Naskah ditulis dalam Bahasa Indonesia atau Bahasa Inggris;

3. Naskah menggunakan istilah yang baku serta bahasa yang baik dan benar;

4. Naskah diketik dengan program Microsoft Word, huruf Cambria, ukuran 12 pts, spasi 1, kertas ukuran A4, 12-17 halaman; 
5. Naskah diserahkan dalam bentuk soft copy ke email redaksi, redaksimamangan@gmail.com

6. Sistematika penulisan artikel:

a) Judul: maksimal 14 kata dalam bahasa Indonesia dan 12 kata dalam bahasa Inggris; ditulis dengan huruf kapital, ukuran 12 pts;

b) Nama Penulis: tanpa mencantuman gelar akademik. Artikel yang ditulis oleh lebih dari satu orang, harus mencantumkan setiap nama penulis, dengan meletakkan nama penulis utama di urutan awal; nama penulis diikuti dengan mencantumkan alamat email.

c) Lembaga: dicantumkan di bawah alamat email setelah nama penulis;

d) Abstrak dan Kata Kunci (keyword): Abstrak ditulis dalam dua bahasa, yaitu Bahasa Inggris dan Bahasa Indonesia. Panjang abstrak maksimal 200 kata, dan kata kunci (keyword) maksimal 5 kata. Abstrak memuat tujuan, metode, dan hasil penelitian;

e) Pendahuluan: berisi latar belakang masalah, konteks penelitian, telaah pustaka, dan tujuan penelitian. Seluruh bagian pendahuluan diuraikan secara terintegrasi dalam bentuk paragraf-paragraf;

f) Literature review atau kerangka teori : bagian ini merupakan uraian penulis tentang penelusuruan penelitian terdahulu atau kajian teoritis yang digunakan dalam artikel. Literature review atau kerangka teori maksimal 2 halaman.

g) Metode Penelitian: berisi uraian tentang rancangan teknis-prosedural penelitia, berupa setting lokasi penelitian, jenis data penelitian, teknik pengumpulan data, analisis data, dan penyajian data. dapat juga ditambahkan paradigma penelitian;

h) Hasil/ Temuan Penelitian/ Analisis: merupakan hasil analisis yang berkaitan dengan pertanyaan penelitian. Setiap temuan data penelitian haur dibahas. Pembahasan berupa pemaknaan, interpretasi, dan pendekatan atau pembacaan teori terhadap data yang diperoleh;

i) Simpulan: bagian ini terdiri dari temuan penelitian yang merupakan jawaban atas pertanyaan penelitian atau merupakan intisari dari hasil pembahasan. Kesimpulan disajikan dalam bentuk paragraf;

j) Daftar Pustaka: hanya memuat sumber-sumber yang dirujuk, dan setiap sumber yang dirujuk harus tercantum dalam daftar pustaka. Rujukan berupa sumber-sumber primer yang terdiri dari hasil penelitian, artikel jurnal, dan penelitian sripsi, tesis dan disertasi;

k) Biodata Penulis: berupa nama, tempat tanggal lahir, alamat, lembaga, alamat email, nomor telepon/HP, pendidikan dan pekerjaan, serta publikasi karya/tulisan terbaru.

\section{Contoh penulisan Daftar Pustaka:}

\section{Buku:}

Anderson, D.W., Vault, V.D \& Dickson, C.E. Problems dan Prospects for the Decades Ahead: Competency Based Teacher Education. Berkeley: McCutchan Publishing Co, 1999.

\section{Buku kumpulan artikel:}

Saukah, A. \& Waseso, M.G. (Eds.). Menulis Artikel untukJurnal Ilmiah (edisi ke-4, cetakan ke-1). Malang: UM Press, 2002.

\section{Artikel dalam buku kumpulan artikel:}

Russel, T. An Alternative Conception: Representing Representation. Dalam P.J. Black \& A. Lucas (Eds.), Children's Informal Ideas in Science (hal. 62-84). London: Routledge, 1998.

\section{Artikel dalam jurnal atau majalah:}

Kansil, C.L. Orientasi Baru Penyelenggaraan Pendidikan Program Profesional dalam Memenuhi Kebutuhan Dunia Industri. Transpor, XX (4): 57-61, 2002.

\section{Artikel dalam koran:}

Pitunov, B. Sekolah Unggulan ataukah Sekolah Pengunggulan? Kompas, hlm. 4 \& 11, 13 Desember, 2002.

\section{Tulisan/berita dalam koran (tanpa nama pengarang):}

Republika. Wanita Kelas Bawah Lebih Mandiri, hal. 3, 22 April 2013. 


\section{Dokumen resmi:}

Pusat Pembinaan dan Pengembangan Bahasa. Pedoman Penulisan Laporan Penelitian. Jakarta: Depdikbud. Undangundang Republik Indonesia Nomor 2 tentang Sistem Pendidikan nasional. Jakarta: PT Armas Duta Jaya, 1978.

\section{Buku terjemahan:}

Ary, D., Jacobs, L.C. \& Razavieh, A. 1976. Pengantar Penelitian Pendidikan. Terjemahan oleh Arif Furchan. Surabaya: Usaha Nasional, 1982.

\section{Skripsi, Tesis, Disertasi, Laporan Penelitian:}

Kuncoro, T. Pengembangan Kurikulum Pelatihan Magang di STM Nasional Malang Jurusan Bangunan, program Studi Bangunan Gedung: Suatu Studi Berdasarkan Kebutuhan Dunia Usaha Jasa Konstruksi. Tesis. Malang: PPS IKIP MALANG, 1996.

\section{Makalah seminar, lokakarya, penataran:}

Waseso, M.G. Isi dan Format Jurnal Ilmiah. Makalah. Seminar Lokakarya Penulisan Artikel dan Pengelolaan Jurnal Ilmiah, Universitas Lambung Mangkurat, Banjarmasin, 9-11 Agustus, 2001.

\section{Internet (karya individual):}

Hitchcock, S., Carr, L. \& Hall, W. A Survey of STM Online Journals, 1990-1995: The Calm before the Storm, 1996. (http:// journal.ecs.soton.ac.uk/survey/survey.html,diunduh 12 Juli 2011).

\section{Internet (artikel dalam jurnal online):}

Kumaidi. 1998. Pengukuran Bekal Awal Belajar dan Pengembangan Tesnya. Jurnal Ilmu Pendidikan. (Online), Jilid 5, No. 4, (http://www.malang.ac.id, diunduh 20 Januari 2011).

\section{Internet (bahan diskusi):}

Wilson, D. 20 November 1995. Summary of Citing Internet Sites. NETTRAIN Discussion List, (Online), (NETTRAIN@ ubvm.cc.buffalo.edu, diunduh 22 Oktober 2010.

\section{Internet (email pribadi):}

Naga, D. S. (ikip-jkt@indo.net.id). 1 Oktober 2011. Artikel untuk Turast. E-mail kepada Subhan Ajrin (subhanajrin@ gmail.com). 


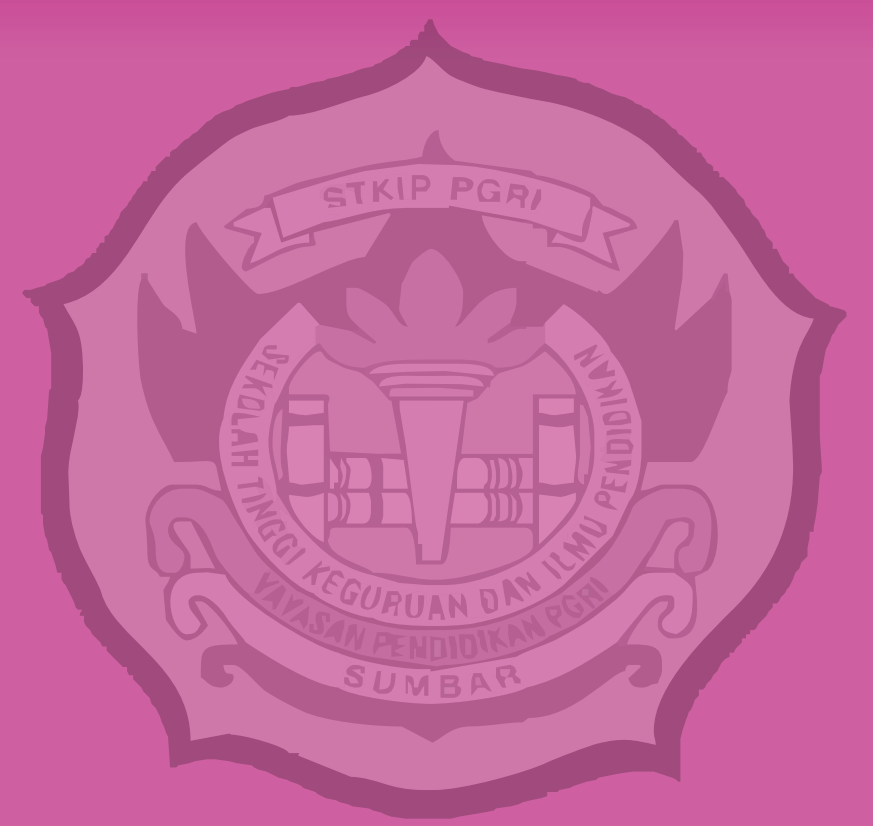

Penerbit:

Laboratorium Program Studi Pendidikan Sosiologi, STKIP PGRI Sumbar Alamat: Kampus STKIP PGRI, Jl. Gunung Pangilun, Padang, Sumatera Barat Email: redaksimamangan@gmail.com 